\title{
RANCANG BANGUN ALAT PENCETAK OPAK PROTOTIPE TEP-01
}

\section{DESIGN OF MOLDING PROTOTYPE OF OPAK TEP-01}

\author{
Wahyu K Sugandi ${ }^{1}$, Asep Yusuf ${ }^{1}$, Adriana Sofyan ${ }^{1}$ \\ ${ }^{1}$ Departemen Teknik Pertanian dan Biosistem Fakultas Teknologi Industri Pertanian, Universitas Padjadjaran \\ ${ }^{\otimes}$ Komunikasi Penulis, Email : sugandiwahyu@gmail.com \\ DOI: http://dx.doi.org/10.23960/jtep-lv7i1.51-62
}

Naskah ini diterima pada 2 Februari 2018; revisi pada 1 Maret 2018;

disetujui untuk dipublikasikan pada 26 April 2018

\begin{abstract}
Opak is a dry and crispy food same as a chips that produce by a small and medium businessess (UKM) in West Java. The regions that produce opak is Sumedang, Majalengka, Cirebon, Tasikmalaya, and Karawang, so it create a variants product of opak. Currently, the molding process of opak is used a traditional tool that called Geplak. Geplak have some weaknesses such a thickness degree and size of opak which not similiar with each others, and for that reason design of molding opak tool is required. This research was doing place in Metal, Wood and Rattan Workshop, Department of Agricultural and Biosystems Engineering - Industrial Technology Faculty of Agriculture , University of Padjadjaran. Engineering method employed through several stages of activities, i.e.; design of opak printing device, functional, structural, and technical analysis. Opak molding device is $1400 \mathrm{~mm}$ of length, $850 \mathrm{~mm}$ of width, and $800 \mathrm{~mm}$ of height. A result tests of opak printing device is have a $3.06 \mathrm{~kg} / \mathrm{hours}$ of actual capacity, have a 4,80 kg/hours of theory capacity, operator power capacity is 343 Watt, and device efficiency is 63,83\%.
\end{abstract}

Keywords : design; molding; opak.

\begin{abstract}
ABSTRAK
Opak merupakan makanan kering dan renyah sejenis dengan kerupuk khas Jawa Barat yang dihasilkan oleh para pengusaha kecil menengah (UKM). Daerah penghasil opak adalah Sumedang, Majalengka, Cirebon, Tasikmalaya, dan Karawang, sehingga terdapat keberagaman produk opak. Saat ini dalam proses pencetakan opak masih menggunakan alat tradisional yang disebut Geplak. Geplak sendiri masih memiliki beberapa kekurangan yaitu diantaranya pada tingkat ketebalan dan ukuran opak yang tidak seragam, untuk itu perlunya dirancang bangun alat pencetak opak. Penelitian ini dilaksanakan di Bengkel Logam, Kayu, Dan Rotan Departemen Teknik Pertanian dan Biosistem - Fakultas Teknologi Industri Pertanian, Universitas Padjajaran. Metode penelitian menggunakan metode rekayasa dengan melalui beberapa tahap proses kegiatan yaitu: perancangan alat pencetak opak, analisis fungsional, analisis struktural, dan analisis teknik. Hasil rancang bangun alat pencetak opak memiliki dimensi, panjang $1400 \mathrm{~mm}$, lebar $850 \mathrm{~mm}$ dan tinggi $800 \mathrm{~mm}$. Hasil pengujian alat pencetak opak ini memiliki kapasitas aktual dan teoritis sebesar $3.06 \mathrm{~kg} / \mathrm{jam}$ dan 4,80 kg/jam, kebutuhan daya operator sebesar $343 \mathrm{Watt}$, dan efisiensi sebesar $63,83 \%$.
\end{abstract}

Kata kunci: rancang bangun; alat pencetak; opak.

\section{PENDAHULUAN}

Opak merupakan makanan kering dan renyah sejenis dengan kerupuk khas Jawa Barat yang terbuat dari tepung ketan yang diberi bumbu garam, gula, dan bumbu penyedap Opak ketan terdiri dari beberapa jenis yaitu opak asin dan manis, selain berbahan beras ketan ada juga opak yang berbahan dasar singkong. Opak dikenal pertama kali di daerah Sunda Jawa Barat, terutama kawasan Priangan. Opak diproduksi oleh Usaha Kecil Menengah (UKM) yang ada di Jawa Barat, seperti Sumedang, Sukabumi, Tasikmalaya, Cirebon dan daerah-daerah lain.

Pada umumnya opak memiliki dua rasa yaitu manis dan asin. Dengan berkembangnya zaman para produsen opak dituntut untuk lebih kreatif dalam berinovasi agar opak tidak kalah dengan produk lainnya sehingga muncul berbagai macam rasa seperti balado, keju, maupun rasa buah-buahan (Dwijayanti, 2006). Menurut 
penglihatan sepintas, produk opak setiap wilayah mempunyai karakteristik yang berbeda-beda, walaupun menghasilkan produk yang sama. Karena banyaknya daerah di Jawa Barat yang memproduksi opak, maka dapat dipastikan terdapat keberagaman produk. Keberagaman opak diantaranya dapat dilihat dari sisi karakteristik yang ada baik dari ukuran, tekstur, rasa, dan cara pengolahan (Koespradana, 2014).

Produsen opak di daerah Jawa Barat masih menggunakan alat sederhana yang terbuat dari kayu yang biasa disebut "Geplak". Proses pembuatan opak dimulai dari pengukusan beras ketan kemudian ditumbuk. Selesai ditumbuk, adonan tersebut dimasukan kedalam geplak yang nantinya akan mencetak adonan tersebut menjadi lembaran pipih. Lembaran ini lalu dikeringkan selama kurang lebih sehari di bawah terik matahari. Setelah kering, lembaran dipanggang di atas bara api sehingga mengeras dan renyah.

"Geplak" ini masih memilik kekurangan yaitu pada tingkat ketebalan dan ukuran opak yang tidak seragam. Apabila opak memiliki bentuk seragam dan tingkat ketebalan sama maka kualitas opak di mata konsumen akan meningkat sehingga diharapkan permintaan terhadap produk opak akan meningkat.

Selain itu kebutuhan tenaga manusia dalam menggerakkan alat membuat tingkat produktivitas alat menjadi kurang maksimal. Keluhan paling banyak terjadi pada proses pencetakan opak, khususnya penggunaan alat pencetak opak. Alat pencetak opak ini masih kurang ergonomis sehingga menimbulkan banyak keluhan dari para operator seperti rasa pegal pada tangan, punggung dan kaki, maka dengan demikian diperlukan rancang bangun alat pencetak opak.

\section{BAHAN DAN METODE}

\subsection{Alat dan Bahan Penelitian}

Alat yang digunakan pada penelitian dikelompokan menjadi alat konstruksi, alat ukur, dan alat pendukung. Adapun alat konstruksi yang digunakan dalam penelitian adalah sebagai berikut:
1. Mesin gerinda potong Makita tipe Disc $\emptyset=$ $355 \mathrm{~mm}$

2. Las listrik Prado 230 Volt, $250 \mathrm{Amp}$

3. Gerinda tangan Makita $11000 \mathrm{rpm}$

4. Bor tangan Makita $1300 \mathrm{rpm}$

5. Alat pelipat plat Edwards-Truefolds, panjang penjepit $2 \mathrm{~m}$

6. Alat pemotong plat Krisbow, pisau 8 inchi

7. Mesin Frais Krisbow, Maximat V13 Compact.

Alat ukur yang digunakan dalam penelitian adalah sebagai berikut:

1. Meteran

2. Mistar

3. Mistar siku

4. Timbangan

Alat pendukung yang digunakan pada penelitian adalah sebagai berikut:

1. Laptop Acer Aspire 4750

2. Software CAD

3. Kalkulator Casio $f x-85$ ES

Bahan-bahan yang digunakan dalam pembuatan mesin sebagai berikut:

1. Besi siku

2. Besi kanal

3. Plat

4. Pegas

5. Besi poros

6. Ring penahan pegas

7. Baut

Bahan yang digunakan dalam penelitian ini adalah beras ketan sebanyak $2 \mathrm{~kg}$.

\subsection{Metode Penelitian}

Metode penelitian yang digunakan dalam penelitian ini adalah metode rekayasa (engineering), yaitu melakukan suatu kegiatan perancangan (design) yang tidak rutin, sehingga didalamnya terdapat suatu modifikasi dan kontribusi baru, baik dalam bentuk proses maupun produk. Tahapan penenelitian dapat dilihat pada Gambar 1.

\subsection{Perancangan}

\subsubsection{Kriteria Dasar Perancangan}

Perancangan adalah kegiatan awal dari usaha merealisasikan suatu produk yang keberadaannya dibutuhkan oleh masyarakat untuk meringankan hidupnya. Perancangan itu 


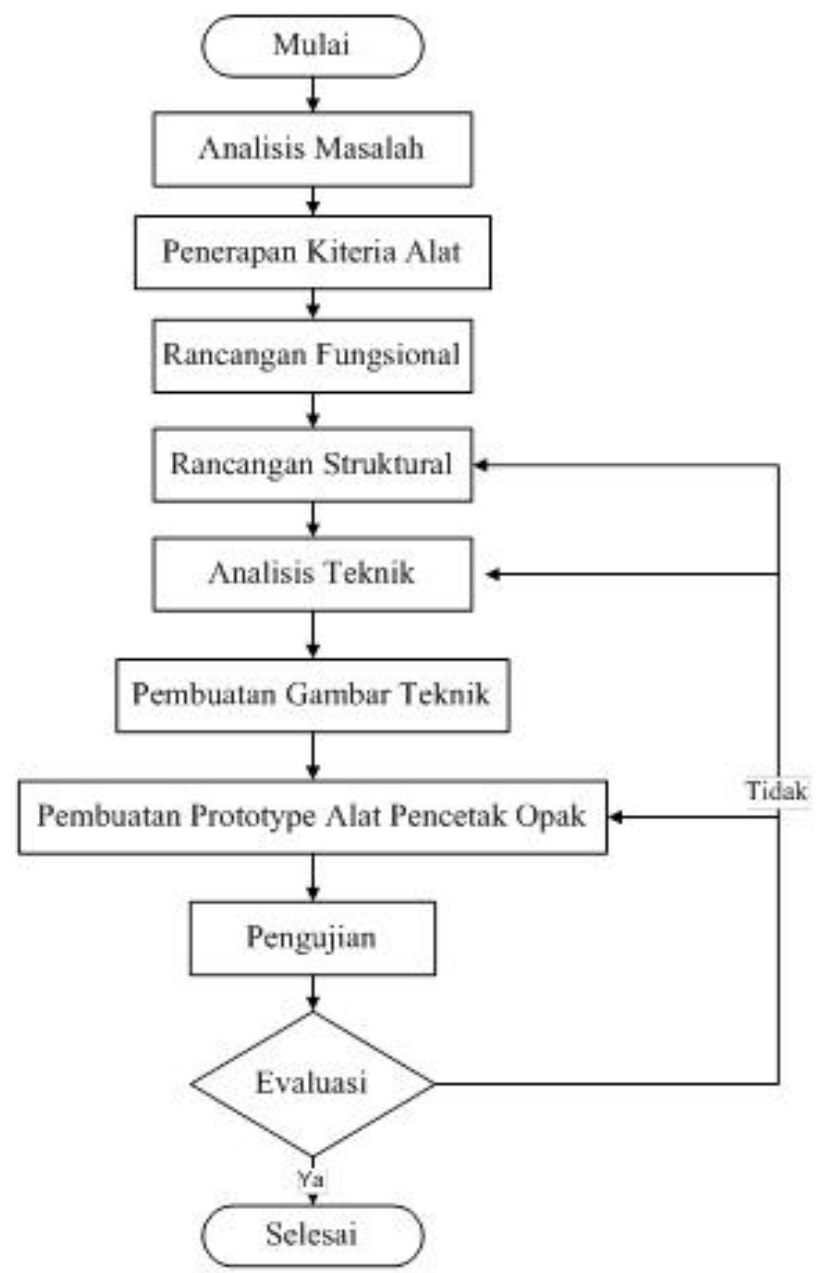

Gambar 1. Diagram Alir Penelitian

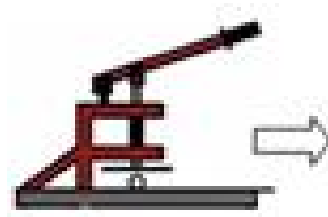

(a)

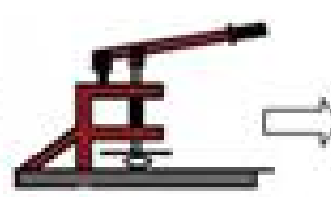

(b)

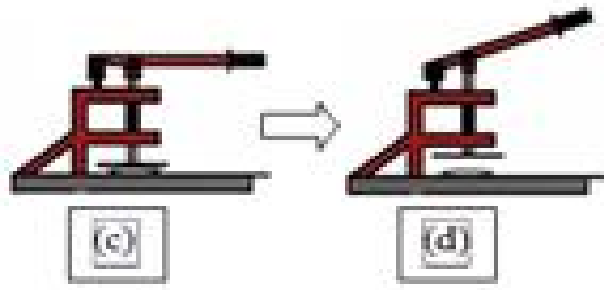

(c)

Gambar 2. Sketsa Mekanisme Kerja Alat Pencetak Opak

sendiri terjadi melalui serangkaian kegiatan yang berurutan

Perancangan alat pencetak opak dilaksanakan berdasarkan beberapa kriteria yang meliputi:

1) Kriteria teknis (mudah dioperasikan, menggunakan tenaga manusia untuk menekan tuas, aman untuk operator).

2) Memiliki kapasitas pencetakan sebesar $5 \mathrm{~kg} /$ jam berdasarkan kebutuhan produsen opak.

3) Untuk kenyamanan di buat tempat duduk.

\subsubsection{Mekanisme Kerja}

Proses pencetakan opak diawali dengan mengambil bahan adonan opak yang sudah ditumbuk sebanyak satu kepal tangan (80 gram) yang di simpan dialas alat pencetak untuk dicetak (Gambar 2), Setelah dicetak adonan akan terbentuk menjadi pipih kemudian dipindahkan pada sebuah nampan, yang disimpan terbalik untuk selanjutnya dijemur. 


\subsubsection{Rancangan Fungsional}

Rancangan Fungsional adalah hasil desain suatu komponen dari sistem yang memiliki fungsi saling mendukung untuk menjalankan sistem tersebut. Penelitian ini akan merancang bangun alat pencetak opak yang digerakan oleh tangan manusia untuk menekan adonan opak yang bulat menjadi pipih. Secara keseluruhan alat pencetak opak dirancang terdiri atas beberapa bagian yang masing-masing dirancang sedemikian rupa sehingga berfungsi sesuai dengan desain yang dinginkan. Agar alat opak ini dapar berfungsi maka diperlukan beberapa fungsi sebagai berikut:

1) Fungsi Rangka

Fungsi rangka ini sebagai komponen yang bertujuan untuk menopang alat pencetak opak.

2) Tuas

Tuas ini berfungsi sebagai tuas penekan alat pencetak opak yang menggunakan tenaga manusia.

3) Papan Pencetak

Papan pencetak ini berfungsi sebagai alat penekan adonan opak yang digerakkan oleh tuas.

4) Alas Pencetak

Alas pencetak opak berfungsi untuk menempatkan bahan adonan opak yang akan dicetak.

\section{5) Penekan}

Terdapat 3 buah rangka penekan yang dihubungkan pada tuas dan pada saat tuas ditekan, maka penekan akan turun ke bawah dan menekan bahan adonan opak yang akan dicetak.

6) Pegas

Pegas berada di atas penekan dan berfungsi untuk membantu tuas kembali ke arah semula setelah melakukan pengoperasian alat pencetak opak.

\subsubsection{Rancangan Struktural}

Rancangan struktural dilakukan untuk menentukan komponen dan struktur dari desain mesin yang akan direalisasikan yang sesuai dengan kriteria untuk menghasilkan alat pencetak opak yang sesuai dengan ya diinginkan. Berikut adalah sketsa dari mesin pencetak opak secara keseluruhan seperti yang disajikan pada Gambar 3.

\section{Rangka mesin}

Rangka alat merupakan penyangga atau dudukan dari semua komponen alat. Rangka berfungsi sebagai penahan beban dari komponen yang berada diatasnya agar komponen alat tetap berada pada posisinya sehingga seluruh komponen alat dapat berfungsi sebagaimana fungsinya. Rangka alat pencetak opak ini menggunakan besi kanal dan besi siku dengan spesifikasi $35 \mathrm{~mm}$ x $35 \mathrm{~mm}$ dan tebal $3 \mathrm{~mm}$ untuk besi siku sedangkan besi kanal $30 \times 50 \times 30$ dengan tebal $3 \mathrm{~mm}$. Sedangkan ukuran rangka yang akan dibangun memiliki dimesi 1400 x 850 x $800 \mathrm{~mm}$. Untuk pemelihan besi kanal sebagai komponen rangka adalah besi kanal memiliki nilai lendutan yang kecil dibanding besi siku sehingga dapat menopang beban rangka penekan alat pencetak opak dan pengerjaanya pun lebih mudah dibandingkan dengan menggunakan besi hollow Berikut adalah sketsa dari rangka alat pencetak opak yang disajikan pada Gambar 4.

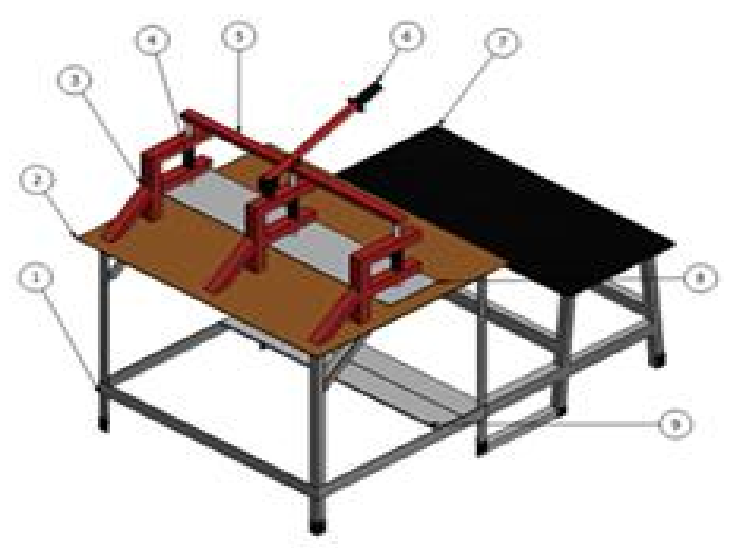

\begin{tabular}{|c|c|}
\hline \multicolumn{2}{|c|}{ Keterangan } \\
\hline 1. & Rangka Mesin \\
\hline 2. & Alas Pencetak \\
\hline 3. & Rangka Pelat Penekan \\
\hline 4. & Pegas \\
\hline 5. & Tangkai Penekan \\
\hline 6. & Tuas Penekan \\
\hline 7. & Kursi \\
\hline 8. & Pelat Penekan \\
\hline 9. & Penyangga Kaki \\
\hline
\end{tabular}

Gambar 3. Sketsa Alat Pencetak Opak 

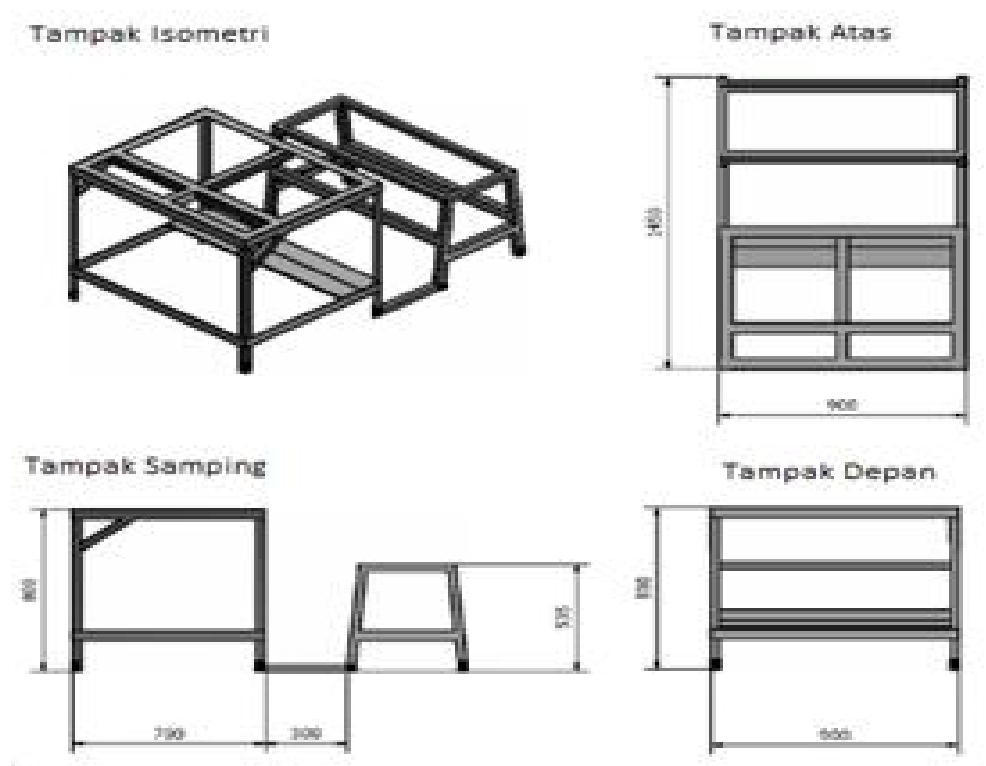

Gambar 4. Rancangan rangka pencetak opak

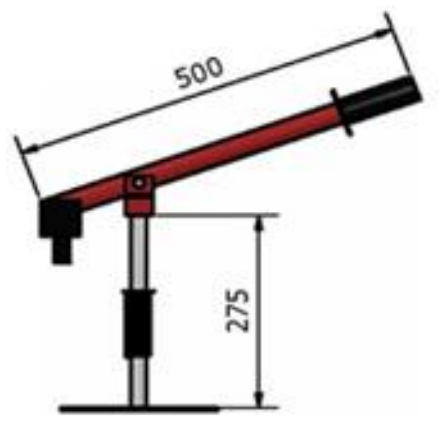

Gambar 5. Tuas Pencetak Opak

\section{Tuas Penekan}

Tuas Penekan berfungsi sebagai genggaman untuk operator alat dalam melakukan proses pencetakan opak. Tuas ini memiliki spesifikasipanjang pipa besi sebesar $50 \mathrm{~cm}$ dan diameter $2,5 \mathrm{~cm}$ yang terbuat dari besi berbentuk silinderyang dilekatkan di salah satu ujung dari batang penekan dengan sudut sebesar $20^{\circ}$ yang dimana sudut yang akan ditentukan diusahakan tetap menjaga faktor kenyamanan operator dalam melakukan operasi alatPada saat proses pencetak opak berlangsung tuas ditekan oleh operator sampai kebawah dan mengghasilkan daya untuk mencetak adonan opak menjadi pipih desain alat terlihat pada Gambar 5.

\section{Pelat Penekan}

Pelat penekan opak ini memiliki spesifikasi panjang $200 \mathrm{~mm}$ dan lebar $1000 \mathrm{~mm}$ dan memilik

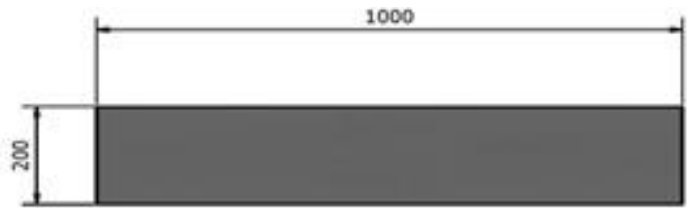

Gambar 6. Papan Pencetak Opak

tebal $2 \mathrm{~mm}$ yang berbentuk persegi panjang dan berfungsi sebagai penekan bahan adonan. Prinsip kerja papan pencetak opak ini adalah saat proses penekanan, penekan terhubung oleh 3 rangka penekan yang akan ditarik oleh tuas. Pada saat di tarik rangka penghubung akan menggerakan papan pencetak tegak lurus kebawah memberi gaya tekan pada adonan opak yang di cetak. Gaya tekan tersebut akan mencetak adonan opak yang berbentuk bulat menjadi pipih. Desain papan pencetak dapat dilihat pada Gambar 6.

\section{Alas Pencetak}

Alas Pencetak opak terbuat dari bahan stainless steel karena kelebihan dari bahan ini adalah tahan karat dengan spesifikasi 1000 x $800 \mathrm{~mm}$. Alas pencetak ini berfungsi sebagai meletakkan bahan adonan opak yang akan dicetak dapat dilihat Gambar 7. 


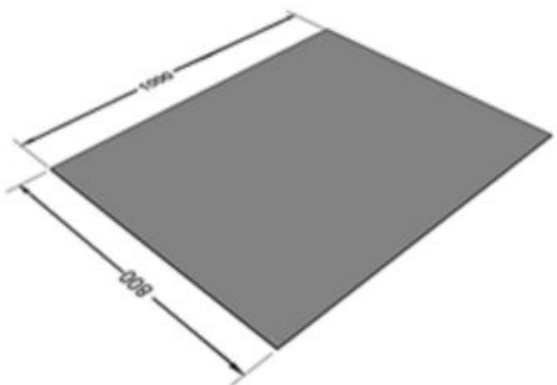

Gambar 7. Alas Pencetak Opak

\section{Rangka Tuas Penekan}

Penekan yang terhubung dengan batang penekan ini berfungsi sebagai pemberi gaya tekan adonan opak pada alas cetakan yang terlatak dibawah, agar adonan opak yang berbentuk bulat jadi menjadi pipih. batang penekan tersebut dihubungkan dengan poros yang bergerak dijalur rangka penekan agar dapat bergerak lurus kebawah. Pada batang penekan terdapat pegas yang berfungsi sebagai menyimpan gaya agar batang penekan dapat kembali seperti semula setelah proses pencetakan desain rangka penekan dapat dilihat Gambar 8.

\subsection{Hasil Analisis Teknik}

Analisis teknik dilakukan untuk mengetahui kelayakan secara teknis dari rancangan alat yang telah dibuat. Analisis teknik yang dilakukan meliputi kebutuhan daya, analisis pegas, analisis kekuatan rangka dan analisis kekuatan las.

\subsection{Kebutuhan Daya}

Kebutuhan daya penekan dilakukan untuk mengetahui daya untuk menggerakan alat pencetak opak. Alat pencetak opak menggunakan tenaga manusia untuk menggerakan tuas pencetak yang ditekan kebawah. Berdasarkan hasil perhitungan didapatkan kebutuhan daya sebesear 343 Watt (denyut nadi 4,91 kkal/menit).

\subsection{Analisis Pegas}

Analisis pegas dilakukan untuk mengetahui daya yang diperlukan untuk mencetak opak. Pegas yang digunakan pada alat pencetak opak ini sebanyak 3 buah dengan ukuran panjang $10 \mathrm{~cm}$ dengan diameter $2,2 \mathrm{~cm}$. berdasarkan hasil perhitungan didapatkan konstanta pegas untuk pencetak opak ini sebesar 65,11 dengan defleksi sebesar $5,7 \mathrm{~cm}$.

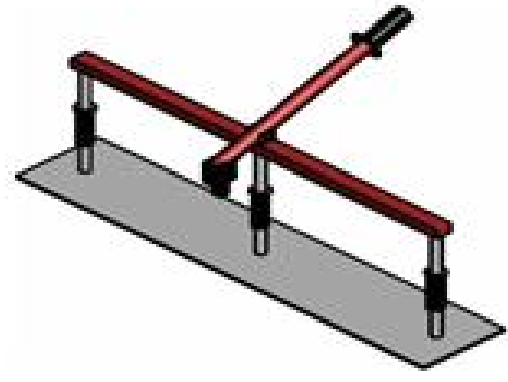

Gambar 8. Rangka Tuas Penekan

\subsection{Analisis Kekuatan Rangka}

Analisis kekuatan rangka diperlukan untuk mengetahui kekuatan rangka yang akan digunakan menopang komponen-komponen alat pencetak opak. Rangka alat pencetak opak terbuat dari besi siku untuk rangka meja sedangkan besi kanal atau besi 'U' untuk rangka penekan. Berdasarkan hasil perhitungan didapat beban yang ditopang rangka sebesar 1043,7 N dengan lendutan yang diizinkan adalah sebesar 3 $\mathrm{mm}$.

\subsection{Analisis Kekuatan Las}

Analisis kekulatan las berfungsi untuk mengetahui gaya yang bekerja pada rangka sehingga rangka dapat menopang komponen mesin lainnya dengan baik. Berdasarkan perhitungan kekuatan las, diketahui gaya maksimal yang mampu ditopang oleh rangka adalah $1043,7 \mathrm{~N}$.

Jika kekuatan las lebih kecil dibandingkan dengan gaya yang ditopang oleh rangka, maka akan terjadi retakan pada sambungan las atau lepas karena bagian rangka yang disambungkan tidak dapat menopang beban yang diterima. Selain dari gaya yang lebih kecil tedapat faktor lain yang mempengaruhi kekuatan las yaitu ketebalan las yang kurang serta pemasangan rangka yang kurang tepat.

\section{HASIL DAN PEMBAHASAN}

\subsection{Hasil Fabrikasi Alat Pencetak Opak}

Hasil rancang bangun Alat Pencetak Opak Prototipe Tep-01 dibuat di Bengkel Logam, Kayu dan Rotan, Fakultas Teknologi Industri Pertanian, Universitas Padjajaran. Alat pencetak opak dirancang untuk dapat digunakan dengan nyaman oleh operator dan dapat meningkatkan kapasitas pencetakan opak dari alat yang sudah 
ada. Mekanisme alat pencetak opak diawali dengan menggambil bahan adonan seberat 10 gram yang sudah dibentuk bulat lalu bahan tersebut disimpan kedalam plastik lalu bahan adonan dimasukan ke alat pencetak kemudian bahan ditekan hingga pipih. Berikut hasil rancang bangun alat pencetak opak yang disajikan pada Gambar 9.

Alat pencetak opak yang telah selesai dibuat dan sesuai dengan gambar rancangan, akan tetapi selama proses pabrikasi ada beberapa perubahan komponen alat yang bertujuan untuk mempermudah pabrikasi tanpa mengubah fungsional dari komponen itu sendiri, adapun komponen alat pencetak opak terdiri dari: rangka, alas pencetak opak, papan pencetak opak, dan penekan. a) Rangka

Rangka alat pencetak opak terbuat dari besi kanal dan besi siku dengan ukuran besi siku dengan ukuran $35 \mathrm{~mm} \times 35 \mathrm{~mm}$ dan tebal $3 \mathrm{~mm}$, sedangkan untuk besi kanal 30 × 50 × 30 dengan tebal $3 \mathrm{~mm}$. Dimensi rangka alat pencetak opak yaitu: panjang $900 \mathrm{~mm}$, lebar $850 \mathrm{~mm}$ dan untuk kolom rangka $800 \mathrm{~mm}$. panjang rangka ditentukan dari kapasitas alat pencetak opak disesuaikan dengan dimensi alas pencetak, untuk lebar rangka disesuiakan dengan dimensi luas papan pencetak opak, sedangkan untuk tinggi kolom rangka diatur sesuai dengan nilai anthropometri sehingga operator tidak mengalami kesulitan pada saat proses pencetakan opak. Bentuk konstruksi rangka disajikan pada Gambar 10.

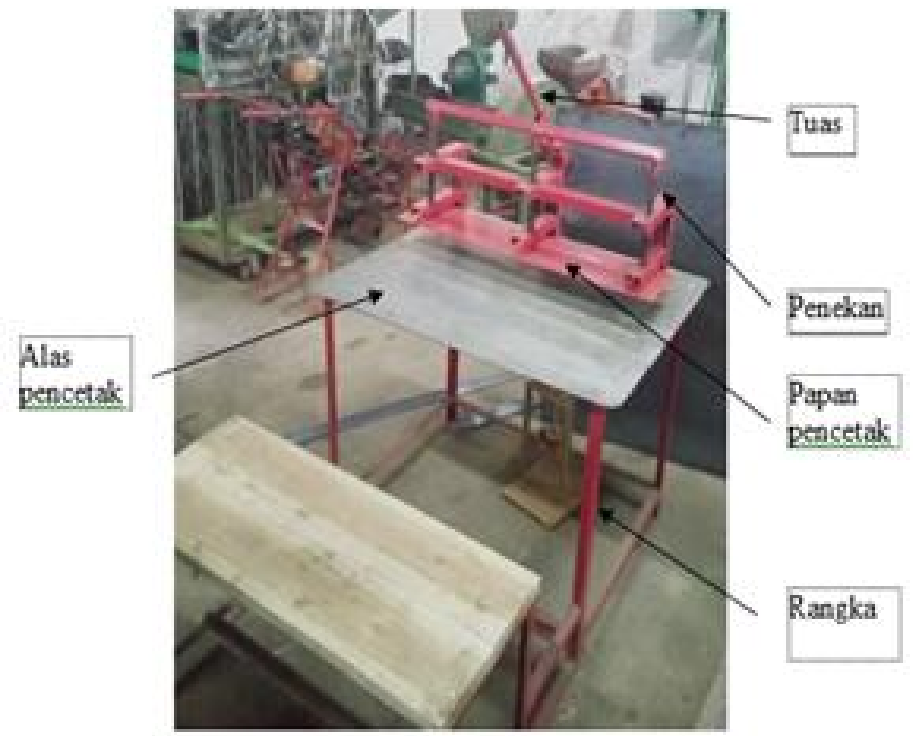

Gambar 9. Alat Pencetak Opak Prototipe TEP - 01

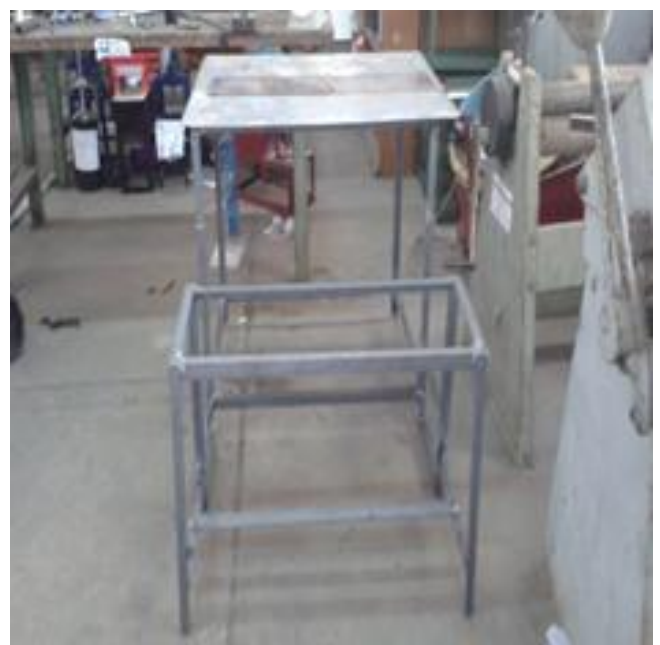

Gambar 10. Rangka Alat Pencetak Opak Prototipe TEP - 01 
Untuk pemilihan besi kanal sebagai komponen rangka adalah besi kanal memiliki nilai lendutan yang kecil dibanding besi siku sehingga dapat menompang beban rangka penekan alat pencetak opak dan pengerjaanya pun lebih mudah dibandingkan dengan menggunakan besi hollow.

\section{b) Alas Pencetak Opak}

Alas pencetak opak ini terbuat dari bahan stainless steel dan memiliki spesifikasi $1000 \mathrm{~mm}$ x $800 \mathrm{~mm}$ dengan ukuran tersebut mampu menaruh bahan adonan opak sesuai kapasitas alat tersebut Bentuk alas pencetak opak disajikan pada Gambar 11.

\section{c) Papan Pencetak Opak}

Papan pencetak opak ini berbahan plat besi memiliki spesifikasi panjang $200 \mathrm{~mm}$ dan lebar $1000 \mathrm{~mm}$ dan memilik tebal $2 \mathrm{~mm}$ yang berbentuk persegi panjang dan berfungsi sebagai penekan bahan adonan.Bentuk papan pencetak opak disajikan pada Gambar 12.

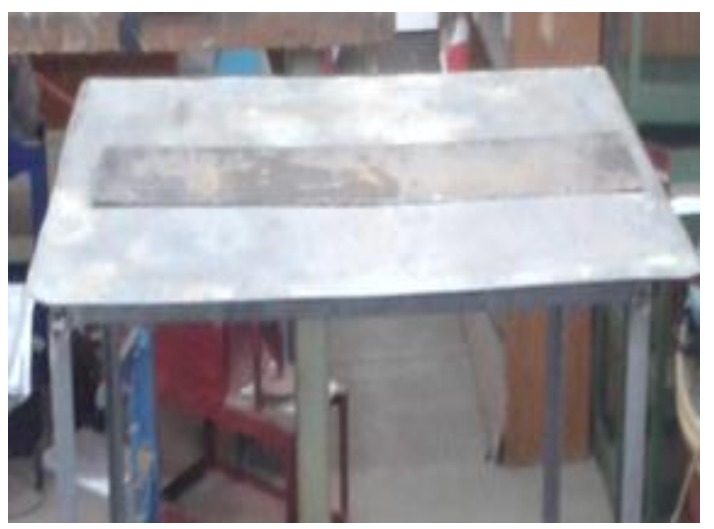

Gambar 11. Alas Pencetak Opak Prototipe TEP $-01$ c) Rangka Tuas Penekan

Rangka Tuas Penekan yang terhubung dengan batang penekan ini berfungsi sebagai memberi gaya tekan adonan opak pada alas cetakan yang terlatak dibawah, agar adonan opak yang berbentuk bulat jadi menjadi pipih.Penekan ini memiliki panjang $425 \mathrm{~mm}$. Bentuk papan pencetak opak disajikan pada Gambar 13.

\subsection{Analis Teknik Alat Pencetak Opak TEP- 01}

3.2.1 Kebutuhan Daya

Kebutuhan daya penekan dilakukan untuk mengetahui daya untuk menggerakan alat pencetak opak. Alat pencetak opak menggunakan tenaga manusia untuk menggerakan tuas pencetak. Berdasarkan hasil pengukuran diperoleh kebutuhan daya untuk mencetak opak adalah 343 Watt.

Pada mekanisme Alat Pencetak Opak Prototipe TEP-01 adalah pertama bahan adonan opak diletakkan di atas alas pencetak lalu papan

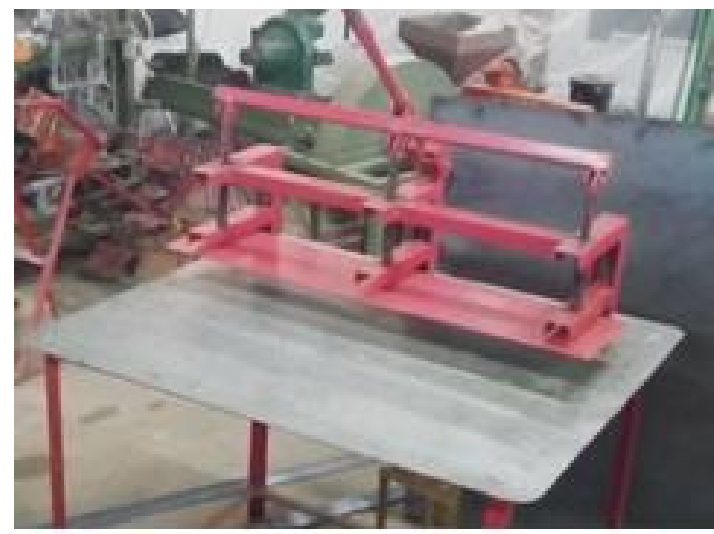

Gambar 12. Papan Pencetak Opak Tampak Atas

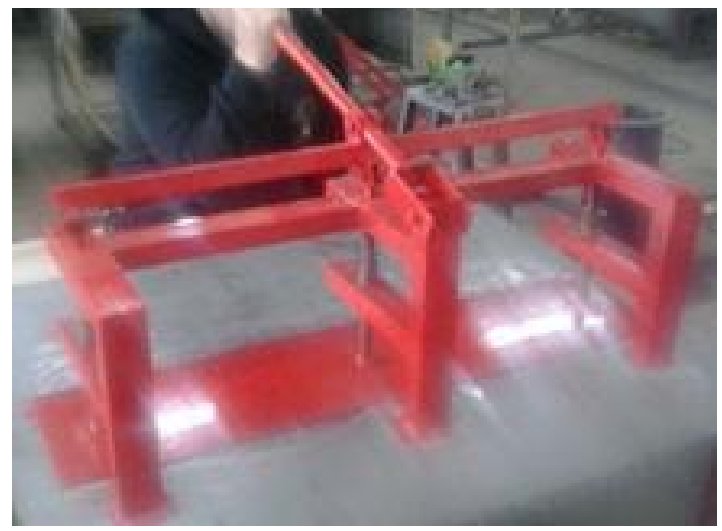

Gambar 13. Rangka Tuas Penekan 
pencetak opak ditekan ke bawah sampai adonan opak berbentuk bulat pipih.Alat ini dapat di gunakan oleh 2 operator dimana 1 operator bertugas untuk mencetak opak dan 1 operator lagi bertugas memotong adonan opak.

\subsubsection{Kapasitas Teoritis Alat Pencetak Opak}

Kapasitas teoritis alat pencetak opak adalah banyak bahan adonan opak yang mampu dicetak dengan per satuan waktu.Yang menentukan faktor kapasitas teoritis alat pencetak opak adalah luas alas pencetak opak yang dapat mencetak opak sebanyak 8 keping opak. Semakin luas alas pencetak maka semakin besar pula kapasitas teoritis alat tersebut. Berdasarkan pengukuran maka didapat kapasitas teoritis alat pencetak opak sebesar $4,8 \mathrm{~kg} / \mathrm{jam}$.

\subsubsection{Kapasitas Aktual Alat Pencetak Opak}

Kapasitas aktual alat pencetak opak diperoleh dengan menghitung jumlah bahan yang dicetak per satuan waktu. Pada penelitian ini digunakan bahan sebesar 1,38 kg bahan adonan opak.

Dari hasil perhitungan yang didapat bahwa besar kapasitas aktual bernilai 3,06 kg/jam. Nilai ini lebih kecil dari kapasitas teoritis mesin yang memiliki nilai $4,80 \mathrm{~kg} / \mathrm{jam}$. Faktor yang mempengaruhi nilai kapasitas aktual dapat disebabkan oleh beberapa faktor diantaranya : waktu proses pencetakan sehingga perlu dilakukan penggulangan pencetakan untuk menjadi bahan adonan yang pipih, jumlah maksimal adonan opak yang dicetak 8 keping, karakteristik fisik bahan adonan juga mempengaruhi dalam pengujian. Untuk meningkatkan kapasitas aktual alat pencetak opak dilakukan beberapa cara diantaranya yaitu: perlu adanya modifikasi pada papan dan alas pencetak agar tidak terdapat gap atau jarak sehingga hasil cetakan dapat memenuhi kriteria yang diinginkan dan menambahan jumlah maksimal adonan opak yang dicetak.

\subsubsection{Efisiensi Alat Pencetak Opak}

Untuk menentukan efisiensi suatu alat dapat dilakukan dengan menghitung perbandingan antara kapasitas aktual dan kapasitas teoritis alat Maka didapat hasil efisiensi alat pencetak opak bernilai 63,83 \% Alat ini memiliki kriteria alat yang baik karena efisiensi alat ini diatas $50 \%$. Rancang bangun alat pencetak opak prototipe
TEP -01 bisa dikatakan berhasil karena memiliki efisiensi alat yang sangat baik dan juga dapat membantu pengrajin opak di Conggeang. Alat ini memiliki efisiensi yang baik karena memiliki nilai aktual sebesar $3,06 \mathrm{~kg} / \mathrm{jam}$ sedangkan untuk teoritisnya sebesar $4,80 \mathrm{~kg} / \mathrm{jam}$.

\subsubsection{Uji Fungsional Alat Pencetak Opak}

Hasil pengujian fungsional yang telah dilakukan menunjukkan bahwa prototipe alat yang dibuat sesuai dengan perancangan yang telah ditentukan, hal ini ditunjukkan dengan alat dapat bekerja mencetak opak dan opak yang dicetak bulat pipih serta berbentuk seragam.Dengan fungsi secara keseluruhan alat maka pemilihan komponen alat sudah sesuai dengan tujuan penggunanya. Adapun pengujian fungsional secara ringkas terlihat pada Tabel 1.

Tabel 1. Hasil Pengujian Fungsional Prototipe Alat Pencetak Opak

\begin{tabular}{cccc}
\hline \multirow{2}{*}{$\begin{array}{c}\text { Adonan } \\
\text { Opak } \\
\text { Yang } \\
\text { Dicetak } \\
\text { (plastik) }\end{array}$} & \multicolumn{2}{c}{ Kriteria Pengamatan } \\
\cline { 2 - 4 } & $\begin{array}{c}\text { Penggerak } \\
\text { Batang } \\
\text { Penekan }\end{array}$ & $\begin{array}{c}\text { Alas } \\
\text { Pencetak }\end{array}$ & $\begin{array}{c}\text { Pelat } \\
\text { Penekan }\end{array}$ \\
\hline 1 & Baik & Baik & Baik \\
\hline 2 & Baik & Baik & Baik \\
\hline 3 & Baik & Baik & Baik \\
\hline 4 & Baik & Baik & Baik \\
\hline 5 & Baik & Baik & Baik \\
\hline 6 & Baik & Baik & Baik \\
\hline 7 & Baik & Baik & Baik \\
\hline
\end{tabular}

Penilaian kriteria pengamatan baik atau buruk pada Tabel 1 ditentukan berdasarkan kondisi struktur alat pencetak opak dan bahan penyusun setiap komponen alat pencetak opak apakah mengalami kerusakan atau tidak, juga berdasarkan pergerakan dari bagian komponen yang bergerak. Awal pengujian fungsional ini yaitu adonan opak plastik ke 1 hanya memperhatikan kinerja dari setiap komponen apakah fungsi yang telah ditetapkan dilakukan dengan baik atau tidak.Pengujian fungsional berikutnya mulai dari plastik 2 sampai plastik 7 mulai dilakukan perbaikan pada bagian komponen yang tidak melakukan fungsinya dengan baik. Pengujian pada plastik adonan opak $1,2,3,4,5,6,7$ komponen sudah dapat melakukan fungsinya dengan baik. Karena 
sebelum melakukan pencetakan ada penambahan plat besi untuk mengganjal bagian bawah alas pencetak, sehingga kerja alat pencetak opak sangat baik.

\subsubsection{Pengujian Kualitatif}

1. Fungsi Kerja Tiap Komponen

Pengujian kualitatif yang dilakukan menunjukkan bahwa prototipe alat sudah sesuai dengan tujuan yang ingin dicapai dengan tingkat kekurangan yang tidak terlalu banyak. Dalam pengujian kualitatif terlihat bahwa setiap komponen berfungsi dengan baik walaupun ada beberapa komponen yang masih berfungsi kurang baik, namun secara keseluruhan kinerja dari alat yang dibuat memenuhi dasar perancangan yang telah ditentukan. Adapun kekurangan yang terjadi adalah saat melakukan proses pencetakan pergerakan naik dan turun dari pegas pada batang penghubung tidak sempurna, karena perlunya pelumasan pegas pada batang penghubung agar proses pencetakan menjadi ringan ketika menggerakan alat pencetak opak.

\section{Keamanan Kerja Alat}

Faktor keamanan kerja alat perlu diperhatikan dalam mengoperasikan alat. Berikut adalah halhal yang perlu diperhatikan untuk menjaga faktor keamanan kerja:

a) Saat pengujian berlangsung tinggi alat pencetak opak adalah $80 \mathrm{~cm}$, tinggi ini sudah memenuhi kriteria faktor fisiologis sehingga tidak akan mengganggu posisi tubuh operator dalam melakukan proses pencetakan opak.

b) Sebaiknya sebelum melakukan proses pencetakan opak operator harus memperhatikan adonan yang akan dicetak agar tidak menepel dengan opak lainya ketika proses pencetakan berlangsung.

c) Setiap menggunakan alat pencetak opak, melakukan pelumasan pada bagian batang penghubung dengan menggunakan stemped tujuannya untuk mencegah operator mengeluarkan tenaga yang berlebih, yang nantinya akan mengakibatkan faktor kelelahan pada operator.

\subsubsection{Aspek Kualitas Alat Pencetak Opak}

Aspek kualitas merupakan gambaran kelebihan dan kekurangan yang ada dalam pembuatan alat pencetak opak ini, adapun keberhasilan adalah: a) Pemilihan pada komponen rangka yang menggunakan besi kanal $U$ dengan ketebalan $3 \mathrm{~mm}$ dan besi siku dengan tebal $3 \mathrm{~mm}$ untuk menopang bagian-bagian alat pencetak opak seperti: penekan, alas pencetak, papan pencetak.

b) Pemilihan pada batang penekan pencetak opak yang sesuai dengan operator.

c) Pemilihan alas pencetak opak yang terbuat dari bahan stainless steel sehingga alas pencetak opak tidak cepat karat

d) Adanya tempat duduk untuk kenyamanan operator saat melakukan pencetakan opak.

Dalam pembuatan alat pencetak opak ini juga masih terdapat banyak kekurangan yang harus diperbaiki, yaitu:

a) Pemilihan tata letak alas pencetak opak dengan rangka alat yang membuat bagian tengah alas pencetak sedikit melengkung kebawah karena kurangnya rapi pada proses penggelasan.

b) Pergerakan batang penghubung yang tidak lebih leluasa untuk bergerak ke atas dan ke bawah karena kurangnya pelumasan pada bagian alas pegas yang terhubung dengan batang penekan.

Dari kelebihan dan kekurangan alat pencetak opak tidak ditemukannya kerusakan yang berarti dari komponen alat saat melakukan pengujian, ini menunjukan pemilihan dan penggunaan jenis komponen pada alat sesuai dengan prinsip kerja yang diinginkan. Namun pada penelitian selanjutnya perlu adanya perbaikan untuk kesempurnaan alat pencetak opak. Perbaikan tersebut berupa alas pencetak opak yang harus sesuai dengan rangka alat agar tidak melengkung kebawah dikarena kan kurang rapinya pada pengelasan dan tata letak adonan opak harus memiliki jarak dengan opak lainnya agar tidak menempel pada saat proses pencetakn berlangsung jarak adonan opak disesuaikan dengan lebarnya papan pencetak opak.

Kekurangan lainya adalah tidak leluasanya batang penghubung untuk bergerak ke atas dan ke bawah yang menyebabkan operator mengeluarkan tenaga lebih saat melakukan pencetakan. Untuk mengatasi kekurangan ini adalah perlunya melakukan pelumasan pada pegas dan batang penghubung, yaitu pada bagian 
alas pegas dimana batang penghubung akan melewati bagian tersebut agar pergerakannya lebih leluasa sehingga tidak menggeluarkan banyak energi pada proses pencetakan.

\subsection{Kajian Ergonomika}

\subsubsection{Hasil Pengujian Antropometri}

Ergonomi tidak bisa lepas dari anthropometri. Menurut Nurmianto (1991) dan Stevenson (1989), anthropometri adalah satu kumpulan data numerik yang berhubungan dengan karakteristik fisik tubuh manusia, ukuran, bentuk dan kekuatan serta penerapan dari data tersebut untuk penanganan masalah desain.

Tujuan dari menganalisis antropometri untuk kelayakan alat pencetak opak prototipe TEP 01 yang sudah dibuat dan ditinjau dari sisi antropometrinya, kajian antropometri dilakukan dibagian tuas penekan alat pencetak opak yang berfungsi sebagai genggaman operator pada saat melakukan pencetakan dan pada bagian papan pencetak opak yang berfungsi sebagai penekan adonan opak.

Pada posisi variable yang diukur untuk pengukuran antropometri pada alat pencetak opak adalah tinggi rangka penekan $800 \mathrm{~mm}$ dari lantai, sedangkan berdasarkan nilai rata-rata tinggi siku untuk ukuran orang Indonesia adalah $97 \mathrm{~cm}$ (dengan asumsi bahwa operator adalah pria), sehingga pada saat menggenggam tuas penekan operator tidak mengalami kesulitan. Untuk tinggi penempatan adonan opak sebesar $600 \mathrm{~mm}$ dari lantai sehingga operator dapat mencetak opak dengan nyaman sehingga tidak harus membungkuk atau memiringkan posisi tubuh sehingga tidak akan menimbulkan kelelahan pada operator, sedangkan untuk tempat duduk operator memiliki tinggi sebesar $525 \mathrm{~mm}$ dari lantai sehingga operator tidak harus membungkuk saat akan mengambil adonan opak yang telah dicetak. Hasil yang didapatkan dari analisis anthropometri ini adalah jarak komponen yang dijadikan acuan perancangan untuk menempatkan posisi komponen agar sesuai dengan kajian ergonomi dimana alat dapat berfungsi dengan baik, ergonomis dan aman bagi operator.

\subsubsection{Daya Manusia}

Daya yang digunakan untuk mengoperasikan alat pencetak opak yang bersumber dari kerja fisik operator yang dikeluarkan oleh otot Dalam kerja fisik, konsumsi energi merupakan faktor yang dapat dijadikan tolak ukur penentu berat atau ringannya suatu pekerjaan.

Dalam menentukan beban kerja alat maka harus di ketahui besarnya energi yang dikeluarkan manusia untuk melakukan suatu kerja. Besarnya energi yang akan dikeluarkan manusia dapat dilakukan dengan pengukuran denyut nadi. Karena dapat mengetahui beban kerja pada saat proses pencetakan opak dengan menggunakan alat pencetak opak prototipe TEP -01 untuk mengukur denyut nadi operator pada saat proses pencetakan berlangsung. Energi yang dikeluarkan manusia pada saat proses pencetakan didapat hasil pengukuran denyut nadi.

Pengukuran denyut nadi dilakukan sebanyak 1 menit, besarnya denyut nadi pada proses pencetakan pada saat operator melakukan pencetakan opak sebanyak 5 menit dengan menggunakan alat pencetak opak. Pada saat operator melakukan proses pencetakan opak selama 1 menit di dapat denyut nadi sebesar 97 sampai dengan 119 denyut nadi. Dari angka tersebut diperoleh denyut nadi rata-rata operator pada saat melukukan proses pencetakan dengan menggunakan alat pencetak opak selama 5 menit adalah 108,60 denyut nadi. Besarnya denyut nadi yang terukur adalah denyut nadi dari keseluruhan rangkain proses pencetakan opak mulai dari proses penimbangan adonan, peletakan adonan, pencetakan adonan sampai pengambilanan adonan. Untuk dapat mengetahui tingkatan beban kerja yang dilakukan operator pada saat melakukan proses pencetakan dengan menggunakan alat pencetak opak dapat dilakukan dengan membandingkan rata-rata denyut nadi operator pada saat melakukan pencetakan opak dengan tabel christensen yang menyajikan data nadi kerja menurut tingkat beban kerja seperti yang di sajikan pada Tabel 2. 
Rancang bangun alat pencetak opak.... (Wahyu KS, Asep Y, and Adriana S)

Tabel 2. Denyut Nadi Menurut Tingkat Beban Kerja

\begin{tabular}{lc}
\hline $\begin{array}{c}\text { Jenis }- \text { Jenis Beban } \\
\text { Kerja }\end{array}$ & $\begin{array}{c}\text { Nadi Kerja (per } \\
\text { menit) }\end{array}$ \\
\hline Sangat ringan & $<75$ \\
\hline Ringan & $75-100$ \\
\hline Agak berat & $100-125$ \\
\hline Berat & $125-150$ \\
\hline Sangat berat & $150-175$ \\
\hline Luar biasa berat & $>175$ \\
\hline
\end{tabular}

Sumber: Sumamur (1989)

Pada proses pencetakan opak dengan menggunakan alat pencetak opak didapat kisaran denyut nadi per menitnya rata - rata 108,6 denyut nadi/menit atau setara dengan 4,91 $\mathrm{kkal} /$ menit (343 watt) maka proses pencetakan opak dengan menggunakan alat pencetak opak termasuk kategori beban kerja agak berat seperti dilihat pada Tabel 2 .

\section{KESIMPULAN}

Dari hasil penelitian yang telah dilakukan dapat diambil kesimpulan diantaranya adalah :

1) Alat Pencetak Opak Prototipe Tep-01 telah berhasil dirancang bangun, terdiri dari komponen utama yaitu: rangka, alas pencetak, tuas, papan pencetak, analisis pegas, rangka penekan dan dapat mencetak opak hingga pipih sesuai dengan karakteristik opak di UKM daerah Sumedang dengan dimensi panjang $900 \mathrm{~mm}$, lebar $850 \mathrm{~mm}$ dan tinggi $800 \mathrm{~mm}$.

2) Kekuatan rangka alat pencetak opak didapat sebesar 1043,7 N sedangkan untuk analisis pegas sebesar 65,11 dengan defleksi sebesar $0,057 \mathrm{~m}$. dan untuk kekuatan las yang mampu menopang rangka sebesar 1043,7 N .

3) Kapasitas teoritis sebesar $4,8 \mathrm{~kg} / \mathrm{jam}$ sedangkan kapasitas aktual alat sebesar 3.06 $\mathrm{kg} / \mathrm{jam}$ sehingga efisiensi alat pencetak opak adalah $63,83 \%$.

4) Alat pencetak ini sudah memenuhi kriteria alat yang baik karena memiliki efisiensi 63,83 $\%$. Alat ini sudah memiliki kriteria alat yang baik karena efisiensi alat ini diatas 50\%.

5) Keergonomisan alat pencetak opak ini sudah sesuai dengan antropometri agar alat opak ini tetap nyaman saat digunakan di UKM opak di Conggeang.

6) Daya yang dibutuhkan untuk mencetak opak adalah 343 Watt.

\section{DAFTAR PUSTAKA}

Dwijayanti, K. 2006. Karakteristik Opak Campuran Beras Sorgum Putih Genotif 1.1 dari Berbagai Lama Penyosohan Abrasif dengan Beras Ketan Putih. Skripsi. Universitas Padjadjaran.

Koespradana, F. R. 2014. Studi Perbandingan Produk Pangan Tradisional Produksi UKM Berbasis Agroindustri di Jawa Barat (Studi Kasus Opak).Skripsi.Departemen Teknik dan Manajemen Industri Pertanian. Fakultas Teknologi Industri Pertanian. Universitas Padjadjaran.

McLean, W.G., and E.W. Nelson. 1962. Engineering Mechanics: Statics and Dynamics. Schaum's Outline Series. McGraw-Hill. New York.

Nurmianto E. 2004. Ergonomi (Konsep Dasar dan Aplikasinya). Surabaya: Guna Widya

Suma'mur, 1989. Keselamatan Kerja dan Pencegahan Kecelakaan. Cetakan Keempat. Jakarta : CV. Haji Mas Agung.

Singer, F. L., Andrew, P. and Darwin, S. 1995. Kekuatan Bahan. Edisi Ketiga. Erlangga. Jakarta.

Sularso dan Kiyokasu, Suga. 1997. Dasar Perencanaan dan Perancangan Elemen Mesin. Cetakan Kesembilan. Pradnya Paramita. Jakarta. 